This is a pre-edited version of collaboratively written article which appeared in Cultural Studies. You will find the final version of the article here: http://www.tandfonline.com/doi/abs/10.1080/09502386.2014.891630?journalCode=rcu s20\#.VLICiHt4cWI

\title{
New Keywords: Migration and Borders
}

By Maribel Casas-Cortes, Sebastian Cobarrubias, Nicholas De Genova, Glenda Garelli, Giorgio Grappi, Charles Heller, Sabine Hess, Bernd Kasparek, Sandro Mezzadra, Brett Neilson, Irene Peano, Lorenzo Pezzani, John Pickles, Federico Rahola, Lisa Riedner, Stephan Scheel \& Martina Tazzioli

\begin{abstract}
"New Keywords: Migration and Borders" is a collaborative writing project aimed at developing a nexus of terms and concepts that fill-out the contemporary problematic of migration. It moves beyond traditional and critical migration studies by building on cultural studies and post-colonial analyses, and by drawing on a diverse set of longstanding author engagements with migrant movements. The paper is organized in four parts (i) Introduction, (ii) Migration, Knowledge, Politics, (iii) Bordering, and (iv) Migrant Space/Times. The keywords on which we focus are: Migration/Migration Studies; Militant Investigation; Counter-mapping; Border Spectacle; Border Regime; Politics of Protection; Externalization; Migrant Labour; Differential inclusion/exclusion; Migrant struggles; and Subjectivity.
\end{abstract}

\section{Introduction}

It is remarkable that Raymond Williams, in his landmark work, Keywords: A Vocabulary of Culture and Society (1976), has no entry for either "Migration"/ "Immigration" or "Borders." Likewise, in the much more recent compilation on New Keywords: A Revised Vocabulary of Culture and Society (2005), edited by Tony Bennett, Lawrence Grossberg, and Meaghan Morris, "border" and "migration" seem to have once again eluded scrutiny. In their Introduction, Bennett, Grossberg, and Morris (2005, p. xxiii) indicate that they had planned to include an entry on "boundaries", but this did not happen. This is a pity, because boundary and border are words that perfectly meet the two basic criteria mentioned by Raymond Williams $(1985$, p.15) thirty years earlier: "they are significant, binding words in certain activities and their interpretation; 
they are significant, indicative words in certain forms of thought.' New Keywords did respond to a related set of concerns that are crucial to migration studies: sovereignty, diaspora, human rights, mobility, post-colonialism, and race, among others, but each of these keywords, we would argue, nevertheless defines a substantially different (if undoubtedly related) problem-space corresponding to a somewhat distinct sociocultural and historical conjuncture. Hence, the absence of the keywords that we propose here was equally a result of the fact that borders and migration had not yet fully emerged as a problem-space for cultural studies. This is not surprising. The discursive currency of these terms, and much of what has come to be commonplace in popular understandings about borders and migration, is the product of a rather short (global) history. Of course, this is not to disregard the complex historical background for the contemporary prominence of these figures. It is, however, to signal the momentous arrival of Migration and Borders as indispensable conceptual categories for cultural studies today.

In the following pages, we propose to call critical attention to the ever increasing prominence of migration and borders as key figures for apprehending "culture and society" in our contemporary (global) present.

In his classic text, Williams opens his discussion with a reflection on how particular terms and phrases acquire quite discrepant and even contrary meanings over time and across space, such that the same words -- and the conceptual categories that they index - can be so variously deployed, from one idiomatic usage to the next, as to appear to no longer refer to the same things. Williams (1976/ 1983, p.11) remarks:

"When we come to say 'we just don't speak the same language' we mean [...] that we have different immediate values or different kinds of valuation, or that we are aware, often intangibly, of different formations and distributions of energy and interest." 
It was of course part of Williams' larger project in his Keywords to supply a multi-layered exegesis for the numerous and subtly heterogeneous ways that the same words served a variety of often contradictory analytical purposes or epistemic ends. In this rather more modest endeavor, we will not pursue anything resembling that sort of hermeneutic enterprise. Nonetheless, we do want to affirm the existence here of a different formation and distribution of energy and interest around the thematic of Migration and Borders, distinguished by different immediate values and distinct kinds of valuation. If we appear to be no longer speaking the same language, this indeed is precisely the point.

Hence, we will boldly and unapologetically occupy the lexical and conceptual foreground where these "new" keywords can be established as vital and elementary figures for critical thought and action. Thus, we deliberately propose a variety of formulations of a series of concepts related to the larger thematic of migration and borders as tools for simultaneously deconstructing and reconstituting the very ways that cultural studies scholars can even begin to try to approach this topic. That is to say, we seek to de-sediment the already petrified and domesticated vocabulary that so pervasively circulates around these by-now already banal fixtures of popular discourse and public debate - "migration" and "borders" - in order to expose these keywords for all the unsettling dynamism that they intrinsically ought to convey.

\section{What's "New" about Migration and Borders?}

In the past decade, a new epistemic community working on borders and migration in many parts of the world has emerged. This loosely configured cross-section of networks of migrants, activists, and scholars has become increasingly engaged in attempting to go beyond the established paradigms of both traditional and critical migration studies to create different 
relationships with migrants and migrants' struggles as well as a more open reading of border logics, technologies, and practices.

At the heart of these differences is the attempt to rework the by-now well-worn focus on the image of the border as "wall" and its corresponding concept of the "exclusion" of the migrant. Certainly, these groups do not dispute the stark fact that walls have and are proliferating in the contemporary world or that their effects are very often violent and exclusionary. Quite the opposite: they seek to situate the proliferation of such techniques and technologies of control within broader logics of governmentality and management, to understand the logics that drive states to erect walls in response to the mobility of the migrants who seek to pass through, around, over, or under them. But beyond this focus on governmentality and management, these new intellectual formations in migration and border studies - of which we are a part -- see such a focus on the negative power of borders to be an important limit on how we can think and understand the broader political economy and cultural logics of bordering. By rethinking the logics of borders beyond their apparent role as tools of exclusion and violence, we intend to signal the more open and complex ways in which borders react to diverse kinds of migrant subjectivities and thereby operate to produce differentiated forms of access and "rights." Borders function to allow passage as much as they do to deny it, they work to increase or decelerate the speed of movement as much as they do to prevent or reverse it, and it is in the ways that borders multiply these kinds of subject positions and their corresponding tensions between access and denial, mobility and immobilization, discipline and punishment, freedom and control, that we locate the need for a series of New Keywords of Migration and Borders.

Thirty years ago, it was a similar focus on the changing structure and practices in the social regime of capital that led Stuart Hall and his colleagues to articulate a reading of the ways 
in which Thatcherism and neoliberalism was producing new spaces and subjectivities under the signs of privatization, entrepreneurialism, and individual responsibility. Today, globalization has both deepened and extended these dynamics and altered the effects they have. Far from flattening the world and reducing the significance of borders, the contemporary social regime of capital has multiplied borders and the rights they differentially allocate across populations.

As a result, these changing forms of regulation, management, and control have in turn generated new patterns of knowledge production which actively seek to destabilize the taxonomies and governmental partitions that regulate and delimit differential forms of mobility and inclusion, and which likewise open up the subject positions of theorist, practitioner, and migrant to more relational analysis and cross-cutting practices. Thus, today, in ways that were taken-for-granted in the past, we must ask serious questions about the kinds of distinction that are being drawn between an "economic migrant" and an "asylum seeker," or between someone with papers and someone without them, as these identities are increasingly formalized but also plagued by ever greater incoherence, and as specific forms of mobility and juridical identities are assigned accordingly.

This transformation of practices and concepts has produced what Larry Grossberg (2010) has termed a new problem-space or problematic. Conjunctural analysis in cultural studies is above all about the analysis of historically specific sociocultural contexts and the political constitution of those contexts; it is always engaged with the ways in which particular social formations come into being. This is not a narrowly historicist concern with origins and development, but rather concerns a deep critical sensitivity to the conjunctural and contextual, concerned with the ways in which tensions, contradictions, and crises are negotiated in specific social formations. 
As far as migration is concerned, a new problem-space or problematic began to emerge in the 1990s in many parts of the world in the framework of the critical debates surrounding "globalization" and of the multifarious social movements and struggles crisscrossing it. The formation of a new "gaze" and sensitivity on migration, as well as of a new epistemic community challenging the boundaries of established migration and border studies, was part and parcel of development of such movements and struggles, in which the involvement of migrants was a defining feature. The insurgence of the sans papiers in 1996 in France has an iconic significance in this regard, as well as - on a different level - the launch of the campaign Kein Mensch ist illegal ("No one is illegal") at the Documenta exhibition in Kassel one year later. More generally, the spread across continents of a "NoBorder" politics was an important laboratory for the formation of what we have called a new "gaze" on migration (Anderson, Sharma, and Wright 2009). Some of us first met at "NoBorder" camps and not in academic settings. It is from these meetings that such important research projects as "Transit Migration" (Transit Migration Forschungsgruppe 2007) or the innovative map of the Gibraltar Strait drawn by the Hackitektura collective in 2004 (http://www.antiatlas.net/en/2013/09/08/hackitecturacritical-cartography-of-gibraltar-2004-spain/) emerged, while other experiences of political activism and investigation, such as the "Frassanito Network" built the background of the intensification of older relations and the building up of new ones in Europe and beyond. The contestation of the 'Pacific solution', which involved an externalization of the Australian migration regime, took various forms including the Flotilla of 2004 in which activists sailed a yacht from the Australian mainland to the Pacific island of Nauru (Mitropoulos and Neilson 2006). Simultaneously, in the midst of the so-called War on Terror, the United States witnessed the utterly unprecedented nationwide mass mobilization of literally millions of migrants in 2006 
to denounce their prospective criminalization by what would have been the most punitive antiimmigrant legislation in U.S. history.

In the few intervening years, the conditions of capital, labour, and migrant lives have changed sufficiently to re-define the problematic in important ways. For example, the growing and widespread language of "invasion waves" in European border and migration management discourses was given added focus by the 2005 wall jumps in Ceuta, when hundreds of North and West Africa migrants frustrated by the increasingly rigid and draconian policing they were experiencing at the Moroccan border, jumped the wall. It was also in 2005 that the European Union formally signalled that border and migration management was to become a vital task for administration and management with the formation of FRONTEX, the European border and customs management authority

We may identify at least three specific ways in which the figure of "crisis" has shaped or been mobilized by the techniques and practices of border and migration management. First, migration itself has been defined in terms of a crisis that needs to be managed. Second, the importance of migration in the contemporary world will not diminish. Because it is perceived as producing crises for something conventionally thought of as the 'normal' social fabric, the multiplication of the various legal statuses of migrants has generated new demands for administration and institutions of migration and border management. In their book Border as Method (2013), Mezzadra and Neilson have extended this analysis as a new critique of political economy which they refer to in terms of the "multiplication of labour." Third, the enduring depth of the 2007-08 financial crisis and the implementation of a battery of aggressive new austerity politics has had profound effects on the configuration of patterns of migration and the ways in which migrants are responding to the borders they face. These recent changes illustrate in even 
sharper ways the constructed nature of border regimes, as - for example - unemployed Spanish workers migrate to Morocco with an increasing number over-extending their visa stay there, while others become guest knowledge workers in the Ecuadorian university import regime.

In New Keywords: Migration and Borders, our focus is not on "migration and borders" writ large, but on the emergence of the problematic of migration and borders, along with the social mobilizations, interventions and concerns that have emerged around keywords such as "border regime," "border spectacle," "autonomy of migration," or "border as method." Our goal is to focus on critical concepts that deconstruct and transform the established repertoires of both traditional and critical migration studies in productive ways. We see the production and elaboration of new concepts as a crucial aspect of intellectual work and a necessary endeavour with which to enable new forms of politics that can be adequately targeted to the specificities of the historical conjuncture.

As militant researchers who are engaged with one or more migrant movements, we have also elected to compose this essay as a collective experiment, drawing on the collaborative writing of 17 activist scholars working on migration and border studies. Writing this paper has thus been a collaborative effort, what we may describe as a fascinating and mad experiment in writing collectively. Specifically, New Keywords: Migration and Borders brings together 11 keywords that have come increasingly to define a new kind of problem-space around migration. The paper builds on and extends earlier discussions held in London (January/February 2013) at the "Migration and Militant Research" Conference as well as the inaugural gathering of the research network on “The 'European’ Question: Postcolonial Perspectives on Migration, Nation, and Race," both held at Goldsmiths, University of London. 
Central to this endeavour is the need to be sensitive to the 'geographies' of the keywords that we develop. As our initial discussions in London indicated, it is important to challenge the Euro-Atlantic framework of (even 'critical') migration studies, and to engage with other migratory experiences and research. Admittedly, the New Keywords project first arose from discussions otherwise framed in terms of "the 'European' Question," but the real aim of that dialogue was precisely to disrupt the complacent conventions of a kind of residual Eurocentrism in the critical study of migration and borders in the specifically European context, beginning from the insistence on de-familiarizing and de-stabilizing our very preconceptions that we know what "Europe" is and who may be considered to be "European." Nevertheless, the New Keywords: Migration and Borders project is also distinct from that particularly "European" framework for dialogue and debate. Our focus here is not bounded by specific territorial boundaries, but aims to think beyond the Euro-Atlantic focus of (critical) migration studies to include examples such as 'internal migration' in China or the above mentioned Pacific solution to border externalization. With space available here for only rather short entries, we are not able to be fully "global" in the scope of our writing of these new keywords, but we aim nonetheless to repudiate a geographically restricted vision. The stakes of a new critical vocabulary in the study of migration and borders are truly global in scope, and planetary in scale.

$N D G, S M, J P$

\section{References}

Bennett, T., Grossberg, L. and Morris, M. (eds.) 2005 New Keywords: A Revised Vocabulary of Culture and Society. Oxford: Blackwell.

Anderson, B., Sharma, N. and Wright, C. 2009. Editorial: Why No Borders? Refuge, 26(2): 5-18.

Mitropoulos, A. and Neilson, B. 2006. Exceptional Times, Non-Governmental Spacings, and Impolitical Movements. Vacarme, 34 (http://www.vacarme.org/article484.html) 
Williams, R. 1983. Keywords: A Vocabulary of Culture and Society. New York: Oxford University Press (revised edition). 


\section{Migration, Knowledge, Politics}

\section{(1) Migration/Migration Studies}

What is migration? It is a truism to say that mobility has been a distinctive feature of human history, that human history is the history of human mobility. In this keyword we are interested in particular aspects of modern migration: the multifarious and heterogeneous practices of mobility within a field dominated by the state, empire, and capital. The modern state and its bounded discourse of citizenship, first in Europe and then globally, have produced the codes, institutions, and practices that continue to shape migratory policies and experiences across a wide range of geographical settings and scales. In recent years the codes that shape modern migration have been increasingly reworked as they are challenged by a multiplicity of new regional and global actors. Colonial expansion and imperial histories have forged a geography of migration whose effects continue, while modern capitalism has been structurally linked with labour mobility and faced with the problem of its control since its inception.

Migrations have shaped modern history at least since the Atlantic slave trade and the unruly dislocation, enclosure, and dispossession of the rural poor to populate the cities and fuel the booming labor needs of industry in England and other European countries. From historians of slavery in the Americas and critical investigations of the attempts to tame the "coolie beast" in Southeast Asia (Berman 1989), we have learned that these bodies in motion were never "docile." Practices of rebellion and resistance crisscross the history of even the most brutal forms of "forced" migration, a crucial lesson today when governmental as well as scholarly taxonomies and epistemic partitions that define migration confront radical challenges. These challenges are particularly evident in current debates about the "crisis of asylum" and the blurring of the border between "asylum seekers," "refugees," and "economic migrants." 
What is called today "migration studies" has its historical roots in past "ages of migration," most prominently in the time of the great transatlantic migration at the end of the $19^{\text {th }}$ century (just think of the Chicago School of sociology) and the "guest-worker regime" in West Germany and other European countries in the 1950s and 1960s. It is important to begin with such "founding moments" of migration studies at least for three reasons. First, they point to the EuroAtlantic scale of its development, a scale that continues to inform the concepts that are used nowadays to investigate migration across the world. Secondly, they point to the fact that migration studies emerged in the heyday of processes of mass industrialization in the early twentieth century, and particularly within the framework of what is usually called "Fordism". This framework continues to shape the paradigm of migration studies despite the fact that the economy has dramatically changed. Thirdly, a concern for the social and economic "integration" of the migrant has long dominated migration studies. The "point of view of the native", a specific form of "methodological nationalism" has consequently shaped (and very often continues to shape) theoretical frameworks and research projects (De Genova 2005). In these perspectives doxa, commonsense, and public discourses intermingle with "scientific" understandings.

Contemporary migration, at least since the crisis of the early 1970s, challenges all these points. It has become global, compelling us to come to terms with geographically heterogeneous experiences of migration. Even when connected to industrial labour (such as "internal" migration in China), its patterns are very different from classical "Fordist" ones. Moreover, migration has become "turbulent," leading to a multiplication of statuses, subjective positions and experiences within citizenship regimes and labour markets. This has occasioned the "explosion" of established models of "integration" in many parts of the world. 
In recent decades, approaches linked to critical race theory, feminism, labour studies, and transnationalism have productively challenged the boundaries of migration studies. Scholars and activists have highlighted the roles played by race and sex in the shaping of processes of subjection within migratory experiences. At the same time, these approaches have shed light on multifarious practices of "subjectivation" through which migrants challenge these devices on a daily basis, giving rise to relations and practices that facilitate their mobility as well as often unstable ways of staying in place. The emergence of such concepts as "the right to escape" and "autonomy of migration" is part of this challenge to the boundaries of migration studies (Mezzadra 2006; Moulier Boutang 1998; Papadopoulos, Stephenson, and Tsianos 2008). Their most distinctive contribution lies in the emphasis they place on the "subjective" dimensions of migration, on the structural excess that characterizes it with regard both to the order of citizenship and to the interplay of supply and demand on the "labor market."

$S M, B N, S S, F R$

\section{References}

Berman, J. 1989. Taming the Coolie Beast. Plantation Society and the Colonial Order in Southeast Asia, Dehli and New York: Oxford University Press.

De Genova, N. 2005. Working the Boundary. Race, Space, and Illegality in Mexican Chicago, Durham - London: Duke University Press.

Mezzadra, S. 2006. Diritto di Fuga. Migrazioni, Cittadinanza, Globalizzazione Ombre Corte, Verona.

Mezzadra, S. 2011. The Gaze of Autonomy. Capitalism, Migration, and Social Struggles, in V. Squire (ed), The Contested Politics of Mobility: Borderzones and Irregularity, London: Routledge, 121-142.

Moulier Boutang, Y. 1998. De l'esclavage au salariat. Économie historique du salariat bridé, Paris: Puf.

Papadopoulos, D., Stephenson, N., and Tsianos, V. 2008. Escape Routes. Control and Subversion in the 21st Century, London - Ann Arbor, MI: Pluto Press. 


\section{(2) Militant Investigation}

The production and circulation of knowledge around migrations has expanded rapidly in the past decade, resulting in a sort of migration knowledge hype: a multiplication of the types of knowledges being produced under the banner of 'migration' (scholarly contributions, policy dialogues and implementation reports, professional workshops, institutional surveys, advocacy discourses, grants' rationales) and the mushrooming of epistemic communities working on migration issues (academics, policy institutes, non-governmental and intergovernmental organizations, funding institutions, border enforcement apparatuses, etc.). This migration knowledge hype has been sustained by the development of what Sabine Hess (2010) has called "new soft" modes of migration "governance" rooted in knowledge production and working through formats such as migration narratives, policy mobility frameworks, and technical contributions. Deployed as migration knowledge, these governance practices claim to operate in politically neutral ways. They often result in unexamined discourses, architectures, and practices that in turn render knowledge of migration as an object of governmentality (Mezzadra and Ricciardi 2013). Through them research protocols in Migration Studies are standardized and reconstituted as objects of disciplinary investigation and the political and social stakes involved in migrant advocacy are 'professionalized' and diluted.

By contrast, by working towards a political epistemology of migration, militant investigation aims to make two main interventions. First, in contrast to the profiling of migrations as stable targets of research, a militant investigation aims to account for the turbulence of migration practices, the contested politics migrants encounter and produce, the contingent "existence strategies" (Sossi 2007) they mobilize in specific contexts, the varied social geographies of migrant experiences, and the intermittent process of becoming migrant 
and/or being labelled as such. This is not simply a matter of accounting for the instabilities of migration practices and migratory processes. Militant investigation puts these instabilities to work analytically and politically (Colectivo Situaciones 2005).

Second, a militant investigation engages with the power asymmetries that make migrants into subjects of migration knowledge production. It does so by challenging the practices that fix migrants as objects of research, management, care, advocacy, etc. and researchers as subjects who are authors working in a knowledge market, scientists who maintain an impartial distance, advocates who speak for, or activist scholars and scholar activists who act on behalf. Militant investigation maps the distances these asymmetries produce and seeks to highlight the possible disjunctures that might be activated to counter-act these forms of capture. It attempts to destabilize the binaries of researcher and researched, focusing instead on the identification or creation of spaces of engagement and proximity, sites of shared struggle and precarity. And it highlights the diverse practices by which mobile subjects negotiate and contest shifting forms of domination and exploitation.

Such militant investigation and its attempt to create a new political epistemology of migrations takes place in distinct venues, including online networks and discussion platforms, radical academic workshops and conferences, activists' seminars and meetings, websites to circulate counter-knowledges, and collective discussions (e.g., storiemigranti.org, bordermonitoring.eu, watchthemed.net, kritnet.org, migreurop.org). It has also taken on different styles: documentation of experiences, trajectories, and barriers, monitoring and barometer-ing of migrant grassroot struggles, ir-representation, alter-visualization of counter-mapping, and the production of new concepts.

$G G a, M T, S M, B K, I P$ 
References

Bordermonitoring.eu. Politiken, Praktiken, Ereignisse an den Grenzen Europas, http://bordermonitoring.eu/

Colectivo Situaciones. 2005. Something More on Research Militancy: Footnotes on Procedures and (In)Decisions, Ephemera, 5(4): 602-614.

Hess S. 2010. 'We are facilitating states!' An Ethnographic analysis of the ICMPD. In Geiger M and Pécoud A (eds) The politics of international migration management. Basingstoke: Palgrave, pp. 97-117, pp. 98, 106, 108.

Kritnet. Network for Critical Border and Migration Regime Research, http://kritnet.org/

Mezzadra S and Ricciardi, M. (eds.). 2013. Movimenti indisciplinati. Migrazioni, migranti e discipline scientifiche. Verona: Ombre Corte.

Migreurop,http://www.migreurop.org/

Sossi F. 2007. Migrare. Spazi di confinamento e strategie di esistenza. Milano: Il Saggiatore. Storie Migranti, Una storia delle migrazioni attraverso $i$ racconti dei migranti, www.storiemigranti.org

Watch the Med. Transnational Monitoring Against the Violation of Migrants' Rights, http://www.watchthemed.net/

\section{(3) Counter-mapping}

Monitoring, quantifying, mapping, and increasingly live surveillance imaging of illegalized migration are central to the practice of border control. Much of this mapping work charts migrant pathways and crossings to assess 'risks' and develop management strategies. At the same time, pro-migration and migration movements have begun to use mapping tools to navigate the changing spaces and practices of the new border management regime and to think through different ways of spatializing migrant movements and experiences. Such counter-mapping efforts re-situate the logics of borders in terms of barriers to the 'freedom of movement' attempting to create new spatial imaginaries of migrant spatial subjectivities, practices, and 
experiences (Casas and Cobarrubias 2007). Two recent counter-mapping projects illustrate these emerging practices.

Disobedient Gaze is a counter-cartographic response to the extension of the militarized border regime in the Mediterranean Sea which, in recent years, has become a highly surveilled and mapped space. Optical and thermal cameras, sea-, air- and land-borne radars, vessel tracking technologies and satellites constitute an expanding remote sensing apparatus that searches for 'illegalized' activities. However, due to the vastness of the area to be covered and the high volume of commercial and private traffic at sea, the objective of providing full spectrum visibility remains elusive. Instead, more targeted forms of risk assessment to distinguish perceived "threats" such as migration from "normal" productive traffic have been mobilized. These sensing devices create new forms of bordering by filtering "acceptable" and "unacceptable" forms of movement. In recent years, a counter-mapping practice has emerged that challenges this regime of visibility and surveillance. For example, "Watch the Med" is an online mapping platform designed to map with precision violations of migrants' rights at sea and to determine which authorities have responsibility for them. WTM was launched in 2012 as a collaboration among activist groups, NGOs and researchers from the Mediterranean region and beyond. It operates in two ways. First, it creates a "disobedient gaze" that refuses to disclose what the border regime attempts to unveil - the patterns of "illegalized" migration - while focusing its attention on what the border regime attempts to hide; the systemic violence that has caused the deaths of many at the maritime borders of Europe (about 20,000 reported deaths since 1998 http://fortresseurope.blogspot.com/p/la-strage.html). Second, WTM turns surveillance mechanisms back on themselves by demarcating those areas that are being monitored by different technologies and agencies to show what could be "seen" by which border control 
agency in any particular case. This information allows those struggling against border regimes to hold these agencies accountable for the fate of migrants at sea. That is, operating as a collective counter maritime traffic monitoring room, the project consciously repurposes surveillance maps and remotely sensed images as active sites of struggle.

Spaces in Migration takes a different perspective. While migration governance typically maps the physical and political spaces of migration, certain migration struggles moving across borders are generating a series of counter-maps whose aim is to show spaces that are not stable, but open and un-stabilized. "Spaces in Migration" focuses on the codes of visibility through which migrations are charted to be governed and controlled, "ir-representing" the territory and territoriality of migrations by producing a cartography of 'invasions' (Farinelli 2009, p 14, Sossi 2006, p 60). Here counter-mapping focuses on the spaces migrants put in motion after the Tunisian revolution, mapping the contested movement across space and the spatial restructuring of migration governance as it struggles to catch up with these movements. Through these mappings, migrant practices and fields of struggle are articulated as space-making.

$M C, S C, G G a, C H, L P, J P, M T$

\section{References}

Casas-Cortes, M. and Cobarrubias, S. 2007. Drawing Escape Tunnels through Borders: Cartographic Research Experiments by European Social Movements. In L. Mogel and A. Bhagat (eds.) An Atlas of Radical Cartography. Journal of Aesthetics and Protest Press: Los Angeles, pp.51-66.

Heller, C. and Pezzani, L. 2014. A Sea that Kills, a Sea that Witnesses: Making the Sea Account for the Deaths of Migrants at the Maritime Frontier of The EU. In Forensic Architecture. Forensis: The Architecture of Public Truth. Berlin: Sternberg Press.

Farinelli, F. 2009. Crisi della ragione cartografica. Torino: Einaudi Editore.

Habans, R., Sossi, F., Garelli, G., and Tazzioli, M. 2013. Spaces in migration: Counter-Map. In Sossi, F., Garelli, G., and Tazzioli, M. (eds.). Spaces in migration. Postcards of a revolution. London: Pavement Books, pp. 170-171. 
Sossi, F. 2007. Migrare. Spazi di confinamento e strategie di esistenza. Milano: Il Saggiatore.

\section{Bordering}

\section{(4) Border Spectacle}

Borders and boundaries have long figured prominently in the public's attention. Be it the Iron Curtain, the DMZ between North and South Korea, the Limes of the Roman Empire or the Western Frontier in the making of the U.S., borders have often signified a more or less sharp division between here and there, inside and outside, us and them and they have served as a seemingly simple tool for demarcation and control. Even in Western Europe and North America, where boundaries are generally relatively weakly contested and (especially in Europe) are supposed to gradually fade from within, the border retains a clear and categorical function for the management of movement and regulation of migration.

How exactly does the border relate to migration? Nicholas De Genova $(2002,2013)$ highlighted one important aspect of the role of the border when he detailed how the border spectacle, i.e., the enactment of exclusion through the enforcement of the border produces (illegalized) migration as a category and literally and figuratively renders it visible. A representation of illegality is imprinted on selected migration streams and bodies, while other streams and bodies are marked as legal, professional, student, allowable. In the process, migration is made governable. In this regime of governmentality the border spectacle constitutes a performance where illegalization functions along with other devices (waiting, denial, missing paperwork, interview, etc.) to govern and manage migration, to operationalize policies of differential inclusion, and to manage the balance between the needs of labor markets, the demands for rights and in some cases citizenship, and the projection of securitization and 
humanitarianism on the figure of the border (Walters 2001). Images of crowded ships, documentation of deaths at the border, deployments of border guards in so called "hot spots" of border regions and the recourse to military imagery and language all serve to enact the spectacle of the border and deepen the architecture and practices of the border regime.

The spectacle of the border and its predominant representations are not the product of the state alone. This would be to suggest that there is a fixed dichotomy between state and migration. Instead, we prefer to think of the border spectacle as Guy Debord did more generally about spectacle when he suggested that "[t]he spectacle is not a collection of images, rather, it is a social relationship between people that is mediated by images" (1967/1995, p.19). In this sense, the border as social relationship mediated by images is a key site (but not the only one) in which contestation and struggle among a diverse range of actors produce particular forms of representational drift. These include the spectacle of illegality where clandestine crossings of the borders are facilitated by allegedly criminal networks. Illegality and connected forms of exploitation have long been a familiar representation of migration and experience for migrants crossing the border. Since the 1990s and especially since the events of September 11, 2001, the conjoining of migration and security has had a profound impact on migration and society. If social relations of border crossing were previously heavily inflected with a politics of labor or a language of rights, they have since been subordinated to a discourse of security, order and interdiction. This shift gave rise to a new border spectacle, dominated by ever more technological conceptions of border enforcement, often involving remote imaging systems, surveillance videos, the development of large-scale databases, code breaking, and the entry of border and migration security surveillance techniques aimed at biopolitical management. New border agencies, such as FRONTEX (the European Agency for the Management of Operational 
Cooperation at the External Borders of the Member States of the European Union) emerged in this conjuncture, rapidly becoming well-funded, powerful, and highly visible actors in this spectacle.

Beyond the state and its security agencies, other instances of the border spectacle have emerged emphasizing violence, suffering and death at the border. This is what William Walters has referred to as the "birth of the humanitarian border" (Walters 2011). The humanitarian border is less interested in military or political security concerns, and instead focuses on a perspective on migrants as victims, individual lost souls to be rescued and cared for. This particular spectacle gives rise to what Walters describes as neo-pastoral power exercised by NGOs and individuals not by state actors, but in most cases with an explicit reference to supra-state norms such as human rights or international law. In the process, its images are transmitted through media and campaigns, creating trans-national networks of care. The effectiveness of the humanitarian border and its form of spectacularization in gaining the consent of the public contrasts with the tensions surrounding the state's management and securitization apparatuses, and it is not surprising that the two forms have increasingly been linked together in recent years with military practices of humanitarian aid and state building, and humanitarian agency engagements with securitization logics and practices.

Every form of border produces its own spectacle, its own representations. When we speak of the border spectacle, we emphasize the need to be aware of these various moments and forms of production and of the power-knowledge-networks that constitute the border regime and give rise to their public image.

$B K, N D G, S H$ 


\section{References}

Debord, G. 1967/1995. The Society of the Spectacle, translated by Donald Nicholson-Smith, New York: Zone Books

De Genova, N. 2002. Migrant 'Illegality' and Deportability in Everyday Life. Annual Review of Anthropology 31, pp. 419-47.

De Genova, N. 2013. Spectacles of migrant 'illegality': the scene of exclusion, the obscene of inclusion. Ethnic and Racial Studies, 36(7), pp. 1180-98.

Walters, W. 2011. Foucault and Frontiers: Notes on the Birth of the Humanitarian Border. In: Ulrich Bröckling, Susanne Krasmann and Thomas Lemke (eds.): Governmentality: Current Issues and Future Challenges. New York, Routledge, 2011, pp. 138-164

\section{(5) Border Regime}

Why do we speak of a border regime, as opposed to simply the border? By turning to 'border regime' we point to an epistemological, conceptual and methodological shift in the way we think about, how we envision, and how we research borders. As William Walters encouraged us to "denaturalize" the border, the border regime symbolizes a radically constructivist approach to the studies of border. This involves not only governmental logics but also the production of borders from and with a perspective of migration.

It is certainly a commonplace in the interdisciplinary field of border studies that the border can only be conceptualized as being shaped and produced by a multiplicity of actors, movements and discourses. But most of these studies still perceive the practices of doing borderwork and making borders as acts and techniques of state and para-state institutions. In contrast, recent work on borders aims to reach beyond the underlying basic binary logic of structure/agency in order to demonstrate how at the border there is no single, unitarian organizing logic at work. Instead, the border constitutes a site of constant encounter, tension, 
conflict and contestation. In this view, migration is a co-constituent of the border as a site of conflict and as a political space. It is the excess of these forces and movements of migration that challenge, cross, and reshape borders, and it is this generative excess that is subsequently stabilized, controlled, and managed by various state agencies and policy schemes as they seek to invoke the border as a stable, controllable and manageable tool of selective or differential inclusion. From this necessity arises a theoretical challenge not only to describe migration as an active force, but to also understand and accommodate how migration intervenes into the very centre of our production of theory (see autonomy of migration). To summarize with Giuseppe Sciortino's words, a regime is a "mix of rather implicit conceptual frames, generations of turf wars among bureaucracies and waves after waves of ,quick fix' to emergencies [... and] allows for gaps, ambiguities and outright strains: the life of a regime is a result of continuous repair work through practices,“ (2004, p. 32) or, in the words of the Transit Migration project, a regime is a "more or less ordered ensemble of practices and knowledge-power-complexes" (Karakayali and Tsianos 2007, p. 13; our translation).

Taking into account migration as a defining force in producing what the border is, and reconceptualizing the border accordingly, requires a methodological shift. Foucault's work on governmentality, Poulantzas' analysis of the state as an aggregate of struggles and forces of society, or the fruitful use of the notion of assemblages in cultural anthropology, all propose to take a more fine-grained contextual perspective on power and encourage a particular sensitivity for unstable dynamics and emerging phenomena, all characteristics which the border exhibits. Each involves an implicit imperative and explicit call to embrace ethnographic methods and approaches to the study of border regimes. Ethnographic border regime analysis starts from the perspective of the movements and trajectories of migration. It not only encourages a multi-sited 
approach common to many ethnographic research designs, but it reaches beyond a narrow understanding of site. The border regime constitutes a multi-dimensional multi-scalar space of conflict and negotiation and thus requires a multi-methodical approach including not only the stock methods of ethnography such as participant observation and interviews, but extending to discourse and policy analysis and genealogical reconstructions of the contemporary while approaching the ever-shifting constellation of the aggregate of opposing forces which is the border through praxeographic research at the time and site of its very emergence. This mixed methods approach aims at an understanding of the transversal, micro-social and porous trajectories and practices of migration, facilitates a detailed analysis of discourses, rationales and programs, large-scale institutions and knowledge-power-complexes and maps their points of intersection, encounter and interpenetration.

While it certainly does not hold true for every border, borders today are one predominant technology of governing mobile populations and othering them as migration. But as the border constitutes a site of contestation and struggle, a perspective informed by regime analysis allows us to understand the social, economic, political and even cultural conditions of today's borders. Furthermore, it allows for a perspective of struggle and resistance and the implicit possibility that borders constitute a merely temporary feature of the contemporary world.

$B K, N D G, S H$

\section{References}

Walters, W. 2002. Mapping Schengenland: Denaturalizing the Border. In: Environment and Planning D: Society and Space, 20(5), pp. 561-80.

Karakayali, S. and Tsianos, V. 2007. Movements that matter! Eine Einleitung. In: Transit Migration Research Group (eds.)(2007): Turbulente Ränder. Neue Perspektiven auf Migration an den Grenzen Europas. Bielefeld, pp. 7-17.

Sciortino, Giuseppe (2004) Between Phantoms and necessary Evils. Some Critical Points in the 
study of Irregular Migration to Western Europe. In: IMIS-Beiträge. Migration and the Regulation of Social Integration, 24, pp. 17-43

\section{(6) Politics of Protection}

Politics of protection signals the attempt to make visible the politics at play in the existing refugee protection regime. While the latter tends to be presented as strictly humanitarian and apolitical, it is becoming increasingly clear that the provision of protection cannot be thought outside of the political sphere. For instance, the statute of the United Nations High Commissioner for Refugees (UNHCR) stipulates that its work "shall be of an entirely nonpolitical character; it shall be humanitarian and social and shall relate, as a rule, to groups and categories of refugees [...]." But the specified restriction of UNHCR's agenda indicates already that the provision of protection, the very essence of the humanitarian enterprise, can never be "entirely non-political" since it is interrelated with a set of highly political questions: Who can legitimately claim a need for protection? Against which dangers shall protection be offered? Who is supposed to do the protecting? What are the terms and conditions of the protection provided? And whose voice is heard in debates stirred by these questions? (Huysmans 2006).

These questions permit us to identify the present refugee protection regime as a partitioning instrument, which produces more rejected refugees than ones with 'status', and effectively intensifies the precarious existence for many while offering protection to a few (Garelli and Tazzioli, 2013; Tazzioli 2013). Those offered protection are in turn administered by a protection regime that deprives them of their political agency by portraying them as helpless victims and by reducing them to a bundle of material needs (Nyers 2006). The victimization of refugees, while legitimizing UNHCR and multiple other actors as their protectors, also explains the authoritarian dimension of the existing protection regime. We use this term -'authoritarian'-- to highlight the fact that while the refugee protection regime is a humanitarian regime, it is only able to provide support to people if they obey and behave as demanded by the protection 
regime. This regime is full of prescriptions specifying how 'good' refugees should behave in order to be eligible for protection: flee to the nearest state, stay in camps, fully cooperate with authorities, accept their decisions irrespective of their outcomes, and leave voluntarily in case of a rejection of your claim.

The humanitarian framework, under which different practices of displacement are administered and varying forms of protection organized, obscures the political context that produces displaced people in the first place: the nation-state order and the violence its reproduction involves. The Geneva Convention defines the refugee in terms of a twofold lack in relation to the posited norm of the nation-state citizen: a lack of protection by a state order and a lack of political agency outside of a national community. Due to this methodological nationalism, the three "durable solutions" of the protection regime - repatriation to the country of origin, reintegration in the host society, or resettlement to a third country - all aim at transforming the 'anomaly' of refugees back into the 'normalcy' of nation-state citizens. It is through these politics of protection that the supposedly strictly humanitarian protection regime restores the "national order of things" (Malkki 1995), a national order which produces refugees in the first place.

The role of the refugee protection regime as a partitioning instrument points, in turn, to its binary logic, which is based on a distinction between forced (political) and voluntary (economic) migrants. Yet, researchers have convincingly revealed this clear-cut distinction to be empirically untenable, as the motivations for movement are always mixed and in excess of such simple dichotomies. Hence, the academic division between Refugee, Migration and Forced Migration Studies along the narrow definition of the 'refugee' of the Geneva Convention has a crucial disciplining effect both epistemologically and politically. Moreover, by positing a 'wellfounded fear of persecution' as a condition asylum seekers have to meet in order to be counted as legitimate, the refugee protection regime de-legitimizes the majority of migratory movements. 
This criminalizing effect of its binary logic manifests in refugee-status-determination procedures, which do not only certify some claimants as "genuine" refugees, but literally produce "illegal migrants" by officially indicating to rejected claimants that their presence is no longer authorized and is therefore "illegal" (Scheel and Ratfisch, 2014).

Finally, the policies of containment and deterrence (e.g., the interception of refugees, the outsourcing of protection to other countries, the proliferation of multiple short term and subsidiary forms of protection) signal an ongoing restructuring of the protection regime towards a sort of "protection-lite" regime (Gammeltoft-Hansen 2007). With the increasing reluctance of societies of the global North to admit and protect refugees, the recent focus on 'internal displacement' has also become a part of a larger project which seeks to transform the protection regime into one designed for the containment of those for whom there is no regime of social protection, what Duffield $(2008,145)$ has called the "world's non-insured". Yet, rather than calling for a return to the "true" protection regime of the Geneva Convention as a way to counter these developments, the authoritarian dimension, methodological nationalism and the violent effects of the binary logic of this protection regime compel us to look for alternative answers to the questions raised by the politics of protection.

$S S, G G a, M T$

\section{References}

Duffield, M. 2008. Global Civil War: The Non-Insured, International Containment and PostInterventionary Society. Journal of Refugee Studies 21 (2), pp. 145-165.

Gammeltoft-Hansen, T. 2007. The Extraterritorialisation of Asylum and the Advent of "Protection Lite". Working Paper of the Danish Institute for International Studies.

Garelli, G. and Tazzioli M. 2013. Arab Springs Making Space: Territoriality and Moral Geographies for Asylum Seekers in Italy. Environment and Planning D: Society and Space 31(6), pp. 1004-1021. 
Huysmans, J. 2006. Agency and The Politics of Protection: Implications for Security Studies. In The Politics of Protection: Sites of Insecurity and Political Agency, edited by J. Huysmans, A. Dobson and R. Prokhovnik. Oxon and New York: Routledge, pp. 1-18.

Malkki, L. 1995. Refugees and Exile: From 'Refugee Studies' to the National Order of Things. Annual Review of Anthropology 24 (1), pp. 495-523.

Nyers, P. 2006. Rethinking Refugees: Beyond States of Emergency, New York and London: Routledge.

Scheel, S. and Ratfisch, P. 2014. Refugee Protection Meets 'Migration Management': the UNHCR as a Global Police of Populations. Journal of Ethnic and Migration Studies. Forthcoming.

Tazzioli, M. 2013. Migration (in) Crisis and 'People Who Are Not Our Concern. In Sossi, F., Garelli, G., and Tazzioli, M. (eds) (2013) Spaces in migration. Postcards of a revolution. London: Pavement Books, pp. 107-25.

\section{(7) Externalization}

Border externalization refers to the process of territorial and administrative expansion of a given state's migration and border policy to third countries. The process is based on the direct involvement of the externalizing state's border authorities in other countries' sovereign territories, and the outsourcing of border control responsibilities to another country's national surveillance forces. Border externalization changes the understanding of the border by reworking who, where and how the border is practiced. By rethinking borders beyond the dividing line between nation-states and extending the idea of the border into forms of dispersed management practices across several states', externalization is an explicit effort to "stretch the border" in ways that multiply the institutions involved in border management and extend and rework sovereignties in new ways. In this way, the definition of the border increasingly refers not to the territorial limit of the state but to the management practices directed at 'where the migrant is'.

Several examples of externalization have become particularly significant in recent years. 
These include: EU Neighbourhood Policies and the Migration Routes Initiative under the framework of Global Approach to Migration signed in 2005; the historical antecedents of maritime interdiction and detention in the Caribbean; and the current policy of the Pacific Solution by the Australian government. Each raises a series of issues relating to sovereignty and territory, the blurring of inside-outside distinctions, the emergence of the humanitarian/securitarian border, and the question of the agency of the externalized state.

In border externalization management practices the idea of exteriority has been used to displace some sovereign responsibilities and technologies of border control beyond the legally defined boundaries of a given territorial state, increasingly refiguring "methodological nationalism." Their focus has increasingly been on following migrants as they move across different geographical and political spaces and attempting to govern their movement before, at and after the border. As a consequence, border regimes are being redefined in terms of the movement of people and things, new technical apparatuses of surveillance, and new processes of sovereign and supranational government (Andersson 2014; Karakayali and Rigo 2010; Ticktin 2009). If borders are what we have come to assume as the limit of legal sovereignty in international law, we have to ask where state jurisdiction and sovereignty begins and ends in these new border regimes?

One of the main justifications for externalization emerges in the language of humanitarianism. Here externalization has become a fundamental strategy of what William Walters (2011) has been called the "humanitarian border." Such humanitarian actors and discourses play an increasingly important role in contemporary border regimes (Mezzadra and Neilson 2013). In the process, humanitarian and securitarian discourses are simultaneously mobilized to both protect the rights of migrants and to enforce border policing strategies and 
govern migration. The entanglement of humanitarian and securitarian agendas - a hallmark of the EU border regime - has recently been reinforced through the management of tragic events such as those that repeatedly happen around the island of Lampedusa, Italy. Migration management agencies and politicians increasingly respond to such events with calls to mobilize EU border management agencies to block migrants before they attempt to cross dangerous sea borders so that they do not risk their lives in perilous journeys.

Developing "neighbourhoods" for policy mobility has been one of the key instruments of the EU politics of externalization. A "Euro-Med" and a "Euro-East" have been pursued and implemented in foreign countries restructured as regions of EU influence (Algeria, Egypt, Israel, Jordan, Lebanon, Libya, Morocco, Palestine, Syria, Tunisia and, on the other hand, Armenia, Azerbaijan, Belarus, Georgia, Moldova, Russia, Ukraine), in a process of "non-accession integration". Programs of selected mobility and joint patrolling of borderzones have been included as "clauses on migration" in economic agreements and investment rationales, dealing with visa permits on the one hand and border enforcement and repatriation agreements on the other. Further afield, in neighbours-of-neighbours, attempts to coordinate migration management strategies are articulated through experiments such as the Migration Routes Initiative, which reorients border management away from a focus on defending a line (even, if it is a moving frontline) to establish border control as a series of points along an itinerary. It calls for transnational coordination between denominated "countries of origin, transit and destination" to intersect migrants in their journeys, kilometres further away from the target borders. In particular, WestAfrican routes have been highly surveyed and closed-down by a series of experimental transnational police operations such as Operation Hera by FRONTEX and Operation Seahorse 
led by the Spanish government, and these are now being rolled-out across the wider Mediterranean region.

One of the main goals of EU border externalization throughout is "pre-frontier detection" referring to a type of overall intelligence picture of those spaces through which migrant pass, whether they are within the EU or far beyond it. Pre-frontier detection is also one of the declared aims of EUROSUR, the new European external border surveillance system. While EUROSUR is set to be fully operational at the end of 2013, we are already observing the coupling of "prefrontier detection" and "rescue" as a means of migration management at sea. While a constant aim of coastal states and the EU more broadly has been to make neighbouring states responsible for surveilling, intercepting, disembarking and managing illegalized migrants at sea, some of the most visibly violent strategies such as the push-backs between Italy and Libya have come under increasing criticism and the ECHR has recently reaffirmed the principle of non-refoulement. ${ }^{1}$ Faced with this situation, EU agencies and coastal states increasingly aim to detect illegalized migrants leaving the Southern coast of the Mediterranean before they enter the EU's Search and Rescue (SAR) areas. In these areas the corresponding states are responsible for coordinating rescues and disembarking the migrants. Once a vessel has been detected, authorities of the Southern shore are informed of the "distress" of the migrants and asked to coordinate rescue, and thereby to assume de facto responsibility for rescuing and disembarking to third countries. In this way, interception and rescue have become indiscernible practices, and when coupled with pre-frontier detection they constitute a new strategy in which de facto push-backs are operated without EU patrols ever entering into contact with the migrants.

\footnotetext{
${ }^{1}$ Non-refoulement refers to the protections against return or rendition from countries that are signatories to the 1951 Geneva Convention or the 1967 Protocol, which extended the Convention rights.
} 
Neighbouring states and neighbours of neighbours are also crucial actors in the process of border externalization. While EU policies encourage neighboring states to harmonize policies, to act in the place of EU border control agencies, and to ensure that national policies contribute directly to migration management, neighbouring and participating states pursue their own interests, both in multilevel negotiations with the EU over trade and visa preferences, or in domestic politics aimed at reinforcing domestic controls and policing (Cassarino, 2013).

An iconic site in the recent history of externalization is the US Navy base at Guantánamo Bay. Before it was a camp for "enemy combatants," this site was used to detain Haitian migrants who had fled the 1991 coup against the Aristide government and could not be accommodated under agreements with Honduras, Venezuela, Belize, and Trinidad/Tobago. Some 275 of these detainees had their asylum applications stalled on the basis that they were HIV-positive, making Guantánamo the world's first prison camp for HIV-positive people. In 1992, the US Coast Guard began to return migrants intercepted at sea directly to Haiti - a violation of non-refoulement principles with precedent in Reagan's codification of interdiction policy in 1981. A decade later, this action would find a parallel in Australia's interdiction of migrants on the MV Tampa - a Norwegian tanker that rescued 438 migrants, predominantly Afghan Hazaras, from a sinking vessel in August 2001. This was the beginning of the so-called 'Pacific solution', involving the establishment of offshore detention camps on the Pacific island of Nauru and New Guinea's Manus Island and the excision of outlying islands from Australia's "migration zone" (meaning migrants arriving on these territories could not claim asylum). One of the world's most sustained efforts of externalization, the Pacific solution would mutate over the coming years, with openings and closings of the offshore camps, the establishment of a large detention facility on the excised Christmas Island, and botched attempts to broker refugee swap deals with Malaysia. 
In 2013, it would culminate with the Australian Senate's decision to excise the country's mainland from the "migration zone." With this act, which externalizes the entire national territory from itself, the logic of externalization reaches a limit where the distinction inside/outside is not only blurred but exploded.

\section{References}

$S C, M C, G G a, C H, L P, J P, M T$

Andersson, R. 2014. Illegality, Inc.: Clandestine Migration and the Business of Bordering Europe. Berkeley: University of California Press.

Casas-Cortes, M., Cobarrubias, S. and Pickles, J. 2011. Stretching Borders Beyond Sovereign Territories? Mapping EU and Spain's Border Externalization Policies. Geopolitica(s), 2(1), pp. 71-90.

Casas-Cortes, M., Cobarrubias, S. and Pickles, J. 2013. Re-Bordering the Neighbourhood: Europe's Emerging Geographies of Non-Accession Integration. Journal of European Urban and Regional Studies. 20(1) January, pp. 37-58.

Cassarino, J.-P. 2013. Tunisia's New Drivers in Migration Governance. Paper submitted for the 2013 International Studies Association Conference, San Francisco, California, April 3-6, 2013.

Cuttitta, P. 2006. Points and lines. A topography of borders in the global space. ephemera, 6(1), pp.27-39.

Karakayali, S. and Rigo, E. 2010. Mapping the European Space of Circulation. In N. De Genova and N. Peutz. (eds). The Deportation Regime: Sovereignty, Space, and the Freedom of Movement. Durham, NC: Duke University Press, pp. 123-44.

Neilson, B. 2010. Between governance and sovereignty: remaking the borderscape to Australia's north. Local-global journal 8.

Mezzadra, S. and Neilson, B. 2013. Border as method, or, the multiplication of labor. Durham: Duke University Press.

Ticktin, M. 2009. The Offshore Camps of the European Union: At the Border of Humanity. International Affairs Working Paper 2009-03, The New School.

Walters, W. 2011. Foucault and Frontiers: Notes on the Birth of the Humanitarian Border. In U. Bröckling, S. Krasmann and T. Lemke (eds.). Governmentality: Current Issues and Future Challenges, New York: Routledge, pp.138-164. 


\section{Migrant Space/Times}

\section{(8) Migrant Labour}

Approaching globalization as a 'real universal' means recognizing the extension of the social relation of capital at the world level (Balibar 2002, pp.146-76). This spatial extension does not imply the homogenization of capital's concrete forms, but the opposite. It is the intensiveness of capital's development that creates the heterogeneity of global space. This spatial re-organization of labour has multiplied and fragmented the forms of labour and has shown how the wage relation and nation-state have only ever been particular ways of restraining and containing labour power. Both capital and labour have become more mobile, but the forces that control their mobility are far from continuous. This means that the study of migrant labour cannot restrict itself to describing patterns of mobility or work conditions. It also means that the political regulation of migration requires a fundamental rethinking of the concept of migrant labour itself. Recent militant research on migration has attempted to account for the asymmetries and struggles that invest the practices and experiences of mobility by drawing on fields as diverse as global labour history, anticolonial and postcolonial theory, and border studies.

Migrant labour points to the transnational and political dimensions of migration in redefining the labour market (Bauder 2006). It encompasses a multiplicity of combinations of race, gender, life-paths, nationalities, legal status, educational level, and material experiences of work. These combinations create fields of tension crisscrossed by migrants' mobility, social power, and attempts to control mobility by employers, states, and governmental authorities. These fields of tension are discontinuous: from the enforcement of borders as boundaries to regulate and control the labour force to the production and reproduction of differences and "race management" as a way of optimizing capital's operations (Lowe 1996, Roediger \& Esch 2012). 
Migrant labor describes a disjunction between the production and reproduction of the migrant labor force and reveals a general shift of responsibility that follows the capitalist dream of an available labor force disconnected from the need for its reproduction (Burawoy 1976).

Migratory movements exceed attempts to govern, regulate and set fixed roads of mobility. They are a "total social fact" (Castles \& Miller 2009) that constantly redefines the social and political spaces migrants move from, to, and through by means of struggles, experiences of organization, and autonomy. Attempts to grasp the inner and global nature of labour markets by means of mechanistic or hydraulic representations fail for several reasons. The concrete conditions of migrant labour cut across its bureaucratic and legal statuses. Migrant labour highlights the political role of employers, management, and authorities that operate transnationally across political spaces. Global migration patterns reveal new geographies of power and production and provincialize the world: internal migration, so-called South-South migration, migration between bordering states, circular migration, regional migration, and transcontinental migration coexist, separate, and intertwine.

With its double face, the objective legal dimension and the subjective experiential dimension, migrant labour highlights the uneven role of states and other authorities in capitalist development. Paradoxically, it disrupts the transnational political space of capitalism by pointing to the ongoing existence of states and their significance for different subjects: the effective hierarchical nature of citizenship and rights, the redefinition of borders, and the use of legitimate force. Migrant labour also displays the changing political and economic geography of today's world: the erosion of the power and functions of the nation-state and the rise of a constellation of assemblages, authorities, agencies, lateral spaces, regions, zones, enclaves and corridors (Easterling 2012). On the whole, migrant labour is defined by the encounter of migrants with a 
complex set of power technologies that adapt to the need for creating labour power as a commodity, organizing production, opening new ways of accumulation and valorisation, turning ungovernable flows into mobile governable subjects, and negotiating the multiple concrete conditions of the postcolonial world. Being "in one's place out of place" and "out of place in one's place" is a general political dimension of migrant labour.

$G G r, S M, B N$

\section{References}

Balibar, É. 2002. Politics and the Other Scene. London: Verso.

Bauder, H. 2006. Labor Movement. How Migration Regulates Labor Markets, Oxford, Oxford University Press.

Castles, S. and Miller, M.J. 2009. The Age of Migration. International Population Movement in the Modern World, Fourth Edition, New York, Guilford Press.

Easterling, K. 2012. Zone: The Spatial Softwares of Extrastatecraft, Design Observer, http://places.designobserver.com/feature/zone-the-spatial-softwares-of-extrastatecraft/34528/.

Lowe, L. (1996), Immigrant Acts: On Asian American Cultural Politics, Duke, Duke University Press.

Roediger, D. and Esch, E. 2012. The Production of Difference: Race and Management of Labor in U.S. History. New York, Oxford University Press.

\section{(9) Differential inclusion/exclusion}

Differential inclusion describes how inclusion in a sphere, society or realm can involve various degrees of subordination, rule, discrimination, racism, disenfranchisement, exploitation and segmentation. In feminism, it is associated with a theoretical emphasis on difference that prioritizes embodiment and relationality, and informs critical approaches to rights, equality, and power. In antiracist politics, it links to a concern with intersectional forms of discrimination and a questioning of the nation-state as the most strategic site in which to fight them. Stuart Hall (1986) notes how "specific, differentiated forms of incorporation have consistently been 
associated with the appearance of racist, ethnically segmentary and other similar social features." Importantly, he links such processes to the "social regime of capital," providing a precedent for contemporary discussions of differential inclusion with respect to borders, migration, and subjectivity.

Current use of the concept in analysis of migration regimes draws attention to the effects of negotiations between governmental practices, sovereign gestures, the social relation of capital, and the subjective actions and desires of migrants. It differs from the concept of "differential exclusion" (Castles 1995), which describes the incorporation of migrants into some areas of national society (primarily the labour market) and exclusion from others (such as welfare or citizenship). Working in tension and continuity with concepts of exclusion and securitization, such as those associated with the simplistic notion of Fortress Europe, differential inclusion registers the multiplication of migration control devices within, at and beyond the borders of the nation-state (point systems, externalization, conditional freedom of movement, fast-tracked border crossing for elites, short-term labour contracts, etc.) and the multiplication of statuses they imply. It provides a handle for understanding the link between migration control and regimes of labour management that create different degrees of precarity, vulnerability and freedom by granting and closing access to resources and rights according to economic, individualizing, and racist rationales. The concept thus troubles the conflation of the realm of citizenship with national labour forces and territory, highlighting the ways in which new (internal) borders are policed and crossed by migrant subjectivities - e.g. those between skilled and unskilled labour, victim and agent, or legalized and illegalized. It also provides a means of critically analysing the rhetoric and practices of integration that have emerged in the wake of the crisis of multiculturalism. 
Differential inclusion shines light on the productive aspects of the border and thus works in concert with discussions of illegalization and the temporal control of migrant passages through detention, banishment, the Chinese hukou system, and the like. Placing emphasis on the continuity of exclusion and inclusion, it draws attention to the violence that underlies both. It thus deeply questions programs of social inclusion that imagine a seamless integration of different differences - race, gender, class - into unified political spaces. In differential inclusion, these differences intertwine and separate, sometimes subsuming each other, sometimes conflicting. This is a perspective that needs strongly to be separated from methodological nationalism, or indeed, any topography that assumes inclusion implies proximity to a centre and distance from the margins. Differential inclusion registers how the border has moved to the centre of political life. The concept is essentially paradoxical as it stages a conflict between the containing qualities of inclusion and the capacity of difference to explode notions of social unity or contract and highlight diverse moments of autonomy of migration. To this extent, it is dynamic, unstable, and resistant to reification. Often the rationale of migration control is reduced to a single logic - e.g. capital/labour, post-colonialism, or securitization. The concept of differential inclusion registers the multiplication of migrant statuses in ways that allow a more complex view of the conflictual interweaving of such ways of governing and the mutating sovereignties associated with them.

$S M, B N, L R, S S, G G a, M T, F R$

\section{References}

Castles, S. 1995. How Nation-States Respond to Immigration and Ethnic Diversity. New Community 21 (3), pp. 293-308.

Crenshaw, K.W. 2011. Demarginalising the intersection of race and sex. A black feminist critique of anti-discrimination doctrine, feminist theory, and anti-racist politics. In Framing 
Intersectionality: Debates on a Multi-Faceted Concept in Gender Studies. H. Lutz, M.T. Herrera Vivar and L. Supik (eds.). Farnham: Ashgate, pp. 25-42. (editor note: tbe)

Hall, S. 1986. Gramsci's Relevance for the Study of Race and Ethnicity. Journal of Communication Inquiry 10 (2), pp. 5-27.

Luibhéid, E. 2002. Entry Denied. Controlling Sexuality at the Border. Minneapolis and London University of Minnesota Press. (editor note: tbe)

\section{(10) Migrant struggles}

"Migrant struggles" encapsulates at least two distinct meanings and refers to an array of different migrant experiences. First, "migrant struggles" indicates more or less organized struggles in which migrants openly challenge, defeat, escape or trouble the dominant politics of mobility (including border control, detention, and deportation), or the regime of labour, or the space of citizenship (De Genova 2010; Squires 2011). Second, "migrant struggles" refers to the daily strategies, refusals, and resistances through which migrants enact their (contested) presence -even if they are not expressed or manifested as "political" battles demanding something in particular (Papadopoulos, Stephenson, and Tsianos 2008). These two meanings highlight the heterogeneity of migrant conditions and the diverse ways in which migrants are confronted with and struggle with power(s): struggles at the border, but also before and beyond the border line; struggles that are visible in the public arena or that remain relatively invisible. Thus, as a keyword, "migrant struggles" underscores that migration is itself a field of struggle, while it nonetheless pluralizes the very category of migration. Hence, this concept also suggests that any possible common ground of struggles cannot be taken for granted, and must be actively elaborated, both conceptually and in practice, episodically reinventing new possibilities for alliance or coalition. At the same time, there is a need to recall that some of the most relevant labour struggles in various parts of the world have been at the same time migrant struggles (see 
for instance, the struggles of "internal migrant" workers in China, or the struggles of building cleaners, such as the Justice for Janitors campaign in the US or the Living Wage campaign in the UK).

While daily strategies and practices of resistance are an important component of migrant experiences, but the movements of migration in and of themselves should not be seen as deliberate or direct challenges to any given border regime. We are aware that migration plays a key role in the routine operations and reproduction of capitalism, indeed, that there is no capitalism without migration (Mezzadra 2006; Moulier Boutang 1998). At the same time, however, a complex alchemy of unchaining and taming, selecting and blocking, has always shaped and continues to shape capitalism's relationship with the mobility of labour and thus with migration. Attempts to combine the opening up of channels of officially authorized and accelerated mobility with processes of illegalization and the establishment of a "deportation regime" are clearly visible today. From this point of view, it is important to articulate what precisely can be discerned in these practices of migration that exceeds the strictly "economic" frame of labour recruitment and effective labour subordination. This moment of excess suggests that "migrant struggles" need to be framed also in a more constitutive way, beginning with the fact that every practice or experience of migration is situated within and grapples with a specific field of tensions and antagonisms. In this sense, migration is always crisscrossed by and involved in multiple and heterogeneous struggles. This structural relation between "migration" and "struggles" fundamentally derives from the fact that practices of mobility that are labelled as "migrations" are captured, filtered and managed by migration policies and techniques of bordering. Migrations are therefore eminently caught within relations of power. They are located within conflicting fields of force, which are also fields of struggle, within which 
modifying, challenging, or interrupting the configuration of power is always at stake. And at the same time, migration forces the border regime to continuously revise its strategies, working as a constitutive "troubling factor".

Considerable attention has been given over the last two decades to the organized and articulate struggles of the sans-papiers and other illegalized migrants within the spaces of migrant-"receiving" states, as well as the struggles of migrants involved in subverting or circumventing actual borders. Today a twofold shift is occurring, which takes into account forms of struggles which are not perceptible in the ordinary regime of visibility and do not fit into established paradigms of political representation - which means that these struggles are not characterized by the emergence of their subjects on the "scene" of the political. In other words, the second meaning of "migrant struggles" (above) has become more prominent in critical analyses. More broadly, instead of encoding migrant struggles on the basis of the existing political landmarks, the opposite move should be envisaged: migrant struggles force us to question and rethink both the paradigm of political agency and the presumed temporality of political practices. Thus, rather than depicting (illegalized) migrants who mobilize politically as the paradoxically truest manifestation of "active citizenship," it may be more productive to reconceive the political in terms that are no longer reducible to citizenship as such (De Genova 2010). Similarly, the temporality of political practices is usually understood in terms of a process of claims-making, with its insurgent moments, followed by one or another (negative or positive) institutional resolution. Visibility, agency, and collective public mobilizations cannot be the yardsticks for assessing the political stakes of these struggles. In particular, the uneven visibility and fractured relation to time that undocumented migrants play with -due to their "irregular" presence in space - are two features that can facilitate a rethinking of migrant struggles. This 
conception of "migrant struggles" thus helps to unsettle the thresholds of perceptibility through which the politics of migration is approached and challenges the primacy of visibility as the decisive measure of the relevance or force of these struggles. Furthermore, considering the uneven and strategic (in)visibility of migrants, the goal is not to make invisible practices visible on the public stage of (official) Politics but rather to highlight their effective political force and the real impacts of such discordant practices of freedom and resistance.

Most of the time, migrant struggles are concerned with neither representation nor claims for rights nor border policies as such. Rather, they are struggles of (migrant) everyday life: they consist in the mere fact of persisting in a certain space, irrespective of law, rights and the pace of the politics of mobility. The issue of imperceptibility therefore helps to illuminate the more structural meaning of "migrant struggles" whereby migration always ultimately concerns the daily struggles in which migrants are involved, whether to stay someplace or to move on. However, if migration is assumed to be a practice always cross-cut by various struggles, this requires a reconsideration of any exclusive focus on undocumented (extra-legal, "unauthorized") migration, in favour of also interrogating other varieties of migration (including both skilled and unskilled, regular and irregular). If migration implies a struggle in itself, even when it complies with the terms and conditions of the dominant politics of mobility, then it is necessary to consider how the very existence of borders and immigration regimes always already constitute the conditions of possibility, and therefore the conditionalities and intrinsic thresholds of precarity, for all forms of migration.

Finally, incorporating the "turbulences" produced by migrations into political cartography, we could reverse the meaning of this keyword by suggesting that migrants' struggles unsettle the space of the political, generating a "migration of struggles". Such a 
migration of struggles would force us to think both about the ways in which struggles migrate beyond the established borders of the political and about the ways in which they challenge established forms and practices of political struggle which in turn require a radical rethinking of political concepts and keywords.

$M T, N D G, S M, G G a$

\section{References}

De Genova, N. 2010. The Queer Politics of Migration: Reflections on 'Illegality' and Incorrigibility. Studies in Social Justice 4(2), pp. 101-126.

Mezzadr,a S. 2006. Diritto di Fuga. Migrazioni, Cittadinanza, Globalizzazione. Verona: Ombre Corte.

Moulier Boutang, Y. 1998. De l'esclavage au salariat. Economie historique du salariat bridé. Paris: Presses Universitaires de France.

Papadopoulos, D. Stephenson, N., and Tsianos V. 2008. Escape Routes. Control and Subversion in the XXI Century. London: Pluto Press.

Squire V. (ed). 2011. The Contested Politics of Mobility. Borderzones and Irregularity. London: Routledge.

\section{(11) Subjectivity}

In calling for the investigation of migratory practices, experiences and struggles through the lens of subjectivity we first seek to overcome conceptions of migration as a derivative or dependent variable of 'objective' factors like wage differentials or 'structural' forces such as the destruction of subsistence economies through the expansion of capitalism. While these are important factors for explaining migratory movements, they do not account for the desires and aspirations, as well as the deceptions that inform and drive migratory projects. It is this subjective dimension of migration that we seek to highlight with the concept of 'subjectivity', which oscillates between 
the subject as subjected by power and the subject as imbued with the power to transcend the processes of subjection that have shaped it. Technologies of government and technologies of self-emerge as inseparably intertwined. This recognition of subjectivity avoids the voluntaristic and individualistic undertones that haunt the notion of agency. More precisely, it avoids the framing of migrants as atomized individual rational-choice actors confronting external structures. In other words, we want to begin from the assumption that migrants' practices, experiences and struggles cannot be considered in isolation from the discourses, practices, devices, laws and institutions that constitute particular forms of human mobility as 'migration,' and thereby make 'migrants' out of some people who move but not others.

Second, the production of migrant subjectivities is implicated in the constitution of citizenship (Isin 2002). While migration studies often represent migrants in terms of paradigms of exclusion, critical scholarship has increasingly conceived of border and citizenship regimes as differentiation machines, which actively create a relational field of subject positions through processes of selective and differential inclusion (De Genova 2005; Mezzadra and Neilson 2013). In this view, citizenship emerges as a social relation that is as contingent as the "figures of migration and foreignness" against which it is defined. Migration legislation thus resembles a "magic mirror" that reflects not only relations between the citizen and its 'others', but also constructions of national subjectivity. Particular figures of migration like the 'refugee' or the 'illegal migrant' do not so much represent distinct social groups. Rather, the alternating currency of these figures is indicative of particular relations of migration that correlate to certain constellations of border and citizenship regimes (Karakayali and Rigo 2010). Instead of treating 'refugees', 'illegals', 'citizens', 'guest workers' etc. as naturally given phenomena, the lens of 
subjectivity brings out the materiality of the processes, by which these labels make these people intelligible as 'refugees', 'illegals', 'citizens', 'guest workers' and so forth.

Third, the performative dimension of border and citizenship regimes and the subjectivities they produce is, as a result, crucial. As any EU passport holder has felt viscerally when passing through passport control rooms of the Schengen area, the installation of separate lanes for "EU citizens" and "other passports" interpellates them to perform European citizenship and identify with the project of the European Union. Conversely, deportations are performances of sovereign state power as they enact the claimed prerogative of nation-states to control access to their territories. In this way, the deportation of non-citizens constitutes an important 'technology of citizenship', which also plays a key role in the subjectivation of illegalized migrants (Walters 2002). The deportation of some but not all illegalized migrants is also performative in that it disciplines the un-deported majority by investing illegalized migrants with the fear of being deported (De Genova 2010).

What this example highlights is fourth, that affective and emotional dimensions of processes of subjectivation play a key role in both the attempts to govern migration and migratory practices seeking to subvert these. For instance, the government of marriage migration through the scandalization of 'sham' and 'arranged marriages' rests on positing the Western fairytale of 'true' romantic love as devoid of any material interests (Muller Myrdhal 2010). Hence, the 'management' of migration also involves the regulation of affects, emotions and desires as techniques of government. Yet, at the same time it is the multiplicity of subjective desires, hopes and aspirations that animate the projects migrants pursue with their migrations, which is always in excess of their regulation by governmental regimes. In contrast to conceptions of migration as a dependent variable of objective 'factors' or of migrants as rational-choice-actors, a focus on 
migrants' subjectivity underscores this subjective dimension of migration as one of the reasons explaining the persistence of moments of autonomy of migration within ever more pervasive regimes of border and migration control.

SS, NDG, GGa, MT, GGr, IP

\section{References}

De Genova, N. 2005. Working the Boundaries: Race, Space, and "Illegality" in Mexican Chicago. Durham, NC: Duke University Press.

De Genova, N. 2010. The Deportation Regime: Sovereignty, Space, and the Freedom of Movement: Theoretical Overview. In N. De Genova and N. Peutz (eds). The Deportation Regime: Sovereignty, Space, and the Freedom of Movement. Durham, NC: Duke University Press, pp. 33-65.

Isin, E. 2002. Being Political: Genealogies of Citizenship. Minneapolis: University of Minnesota Press.

Karakayali, S. and Rigo, E. 2010. Mapping the European Space of Circulation. In De Genova, N. and Preutz, N. (eds.). The Deportation Regime: Sovereignty, Space, and the Freedom of Movement. Durham: Duke University Press, pp. 123-144.

Mezzadra, S. and Neilson, B. 2013. Border as Method. Durham, NC: Duke University Press.

Muller Myrdhal, E. 2010. Legislating Love: Norwegian Family Reunification Law as a Racial Project. Social \& Cultural Geography 11 (2), pp.103-116.

Walter, W. 2002. Deportation, Expulsion, and the International Police of Aliens. Citizenship Studies, 6(3), pp. 265-292. 